\title{
Students' Perceptions of Factors Contributing to Performance in Accounting Principle Courses
}

\author{
Faisal D Alfordy ${ }^{1} \&$ Rohana Othman ${ }^{1}$ \\ ${ }^{1}$ Department of Accounting, College of Business Administration, University of Hail, Hail, Saudi Arabia \\ Correspondence: Rohana Othman, Department of Accounting, College of Business Administration, Female College \\ Complex in AJA, University of Hail, Hail 55471, Saudi Arabia.
}

Received: December 8, 2020

Accepted: March 29, 2021

Online Published: April 6, 2021

doi:10.5430/ijhe.v10n5p18

URL: https://doi.org/10.5430/ijhe.v10n5p18

\begin{abstract}
Undergraduate students' performance has been extensively studied to identify the critical components in effective teaching and learning pedagogies. This study aims to determine whether the teachers' practices and implementation of Classroom Assessment Techniques (CAT) enhanced students' performance in Accounting Principles' courses and assess students' perceptions concerning the impact of English language proficiency (EP) and the availability of Saudi-centric textbook materials on students' performance. Additionally, this study employed the questionnaire survey approach to gain insights into accounting undergraduates' perceptions of academic performance in Accounting Principles courses. As most students were found to be underachievers, the study outcomes led researchers to propose active learning approaches using CAT as an initiative towards improving students' performance in benefitting the university and positively transforming the teaching and learning environment.
\end{abstract}

Keywords: CAT, English proficiency, academic performance, Accounting Principle courses, effective learning and teaching

\section{Introduction}

Higher Education Institutions (HEIs) were often perceived to accommodate indifferent and unenthusiastic students in quasi-competent graduate development and tolerated cumbersome teaching practices in conventional campuses. The denunciations have driven educational and university authorities towards myriad 'carrot and stick' approaches for improved academic performance. Chickering and Gamson (1987) and Kinzie et al. (2019) argued that undergraduate education improvement required students' and faculty members' commitment and action and further reiteration on undergraduate education benefits from various initiatives; using active learning techniques, giving prompt feedback, communicating high expectations, and respecting diverse talents and learning methods.

The influence of new research initiatives in educational practices resulted in the need to examine past studies under different settings and periods. Moreover, many studies tended to examine specific factors in isolation or with other factors, specifically in America (Romer, 1993) and Europe (Ilie S. \& Lietz P., 2010). The cultural differences dividing Western and traditional Middle Eastern societies were emphasised as the variances potentially influenced the factors affecting student performance, particularly in regional settings.

Studies focusing on students' learning motivations and strategies and the factors hindering the learning process proved vital in acquiring enhanced academic achievements. The Cambridge University Reporter (2003) stated that academic performance was frequently defined in terms of examination performance. Studies on academic performance were generally typified by undergraduate students' examination performance. Academic performance was also depicted (in examination results) as one of the primary goals of educational institutions. Roth et al (1996) and Shareef et al., (2015) asserted that high academic performers were generally high professional achievers.

In the University of Hail, research on the factors impacting students' academic performance remained lacking. Hence, understanding the numerous factors impacting students' academic progress in education was crucial in facilitating academic design strategies for improved learner academic achievement and educational efficiency. Another noteworthy concept involved the environmental assessment of student motivation, achievement, and performance. A robust model on a synthesis of classroom assessment literature and social cognitive learning and motivation theories were also developed to illustrate the environmental role assessment on student motivation and achievement (Gronlund, 2006; Brookhart, 1997; Penuel \& Shepard, 2016; Shepard, et al, 2018; Shepard, 2019). 
Predictably, students' perceptions of the classroom assessment environment influenced motivational beliefs and achievement-related outcomes. In Gronlund (2006), classroom assessment was a regular activity for teachers towards improving the teaching quality and motivating student learning (Gronlund, 2006; Andrade and Brookhart, 2020). Shepard et al. (2018) also emphasised the model integration with motivation and cognitive development that proved essential in classroom assessment. Furthermore, educators affirmed that assessment-related activities in the classroom provided valuable information, hence influencing students' achievement goals (Harlen \& Crick, 2003, Shepard, 2006; Shepard 2019).

In this study, students' academic performance in accounting courses (based on competency assessments) was defined by students' demonstration of accounting skills performance or behaviour traits denoting an adequate comprehension of accounting principles. For example, the University of Hail students' performance in Accounting Principles I and II (ACC101 and ACC102), respectively, were consistently skewed towards the lower performance spectrum (see Figures 1 and 2). The histograms showed the number of students who scored grade A decreased for both ACC101 and ACC102 in 2017. The number of students with Grade C and D remained high since 2013. The main concern is the increase in the number of students who failed. The low performance served as the study impetus, the first objective aimed to determine whether teachers' practices and implementation of CAT in Accounting Principles courses contributed to students' performance. As such, this study determined whether the absence of CAT pedagogy led to poor performance.

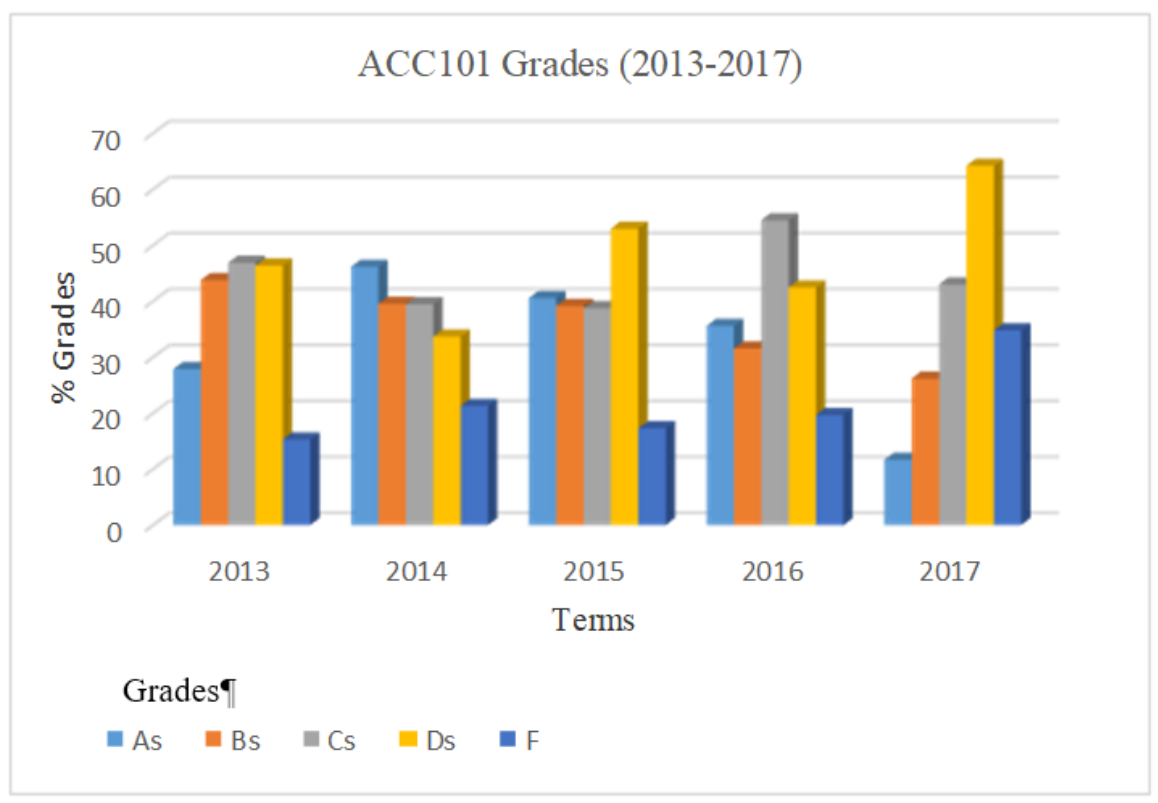

Figure 1. Students' grade distributions in Accounting Principle 1 (ACC101) between 2013 and 2017 


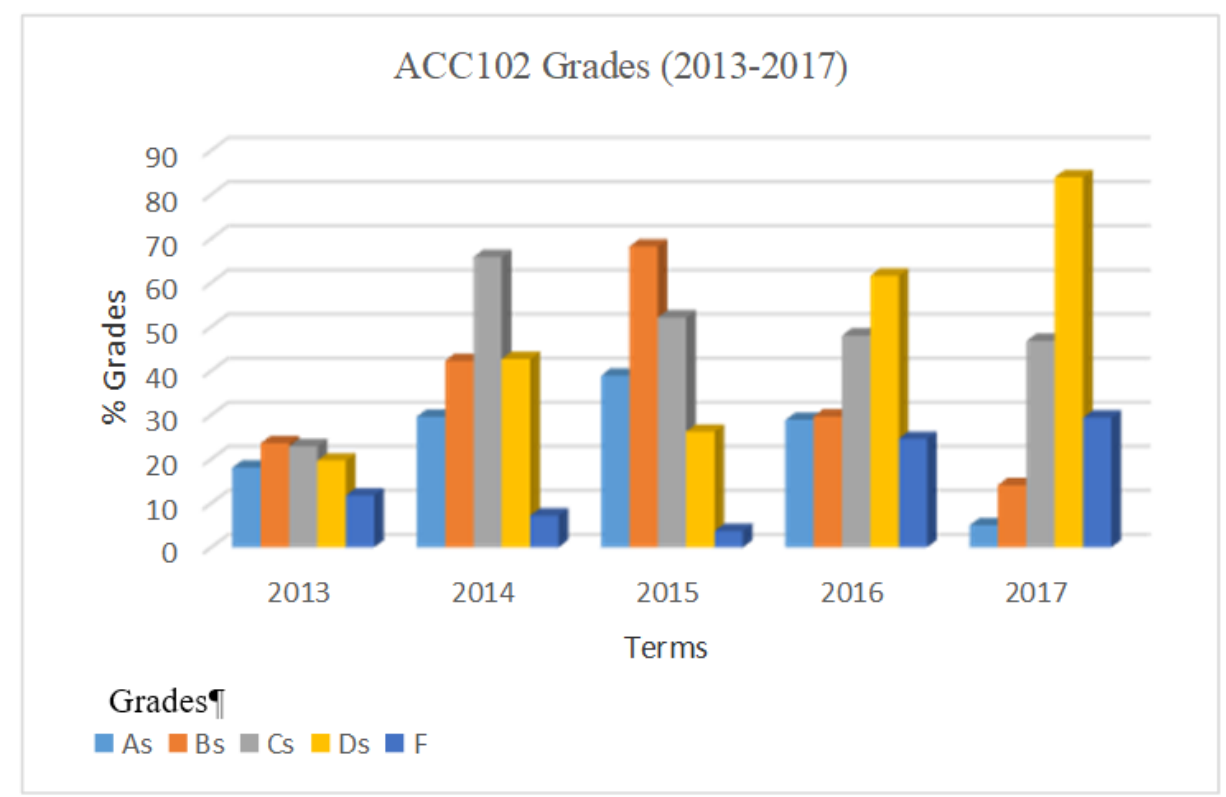

Figure 2. Students' grade distributions in Accounting Principle II (ACC102) between 2013 and 2017

This study also sought to examine students' perceptions of English proficiency (EP) and the unavailability of accounting textbooks with relevant content (oriented to the Saudi Arabian context) that affected students' performance. Another issue concerned the impact of English-Medium Instruction (EMI) on university students' performance achievement in accounting. Therefore, a positive relationship affirmed the English proficiency-academic performance correlation. Hence, an additional study objective served to examine whether the effect of EMI on students' academic performance in HEIs was negative. Ultimately, this paper aims to present the exploratory study outcomes on undergraduate students' performance in accounting principles courses at the University of Hail and provide a window towards the initiation of student performance improvement through CAT.

The paper is structured as follows: Section 1 describes the study background and degree of CAT and English proficiency importance in EMI concerning students' academic achievement to develop the research premise, Section 2 outlines the literature review, Section 3 presents the research methodology, Section 4 highlights the main results and discussions, and Section 5 discusses the study conclusions and limitations.

\subsection{Literature Review}

Accounting literature is replete with academic and professional communities, thus demonstrating an interest in the factors affecting student performance in accounting courses, Certified Public Accountant (CPA) exam performance, and success in the accounting profession (Vruwink et al., 1987; Onay \& Benligiray, 2018; Papageorgiou \& Callaghan, 2020). Other factors, including students' learning styles, instructors' teaching styles, and the potential mismatch of both styles were associated with overall student performance (Visser et al., 2006; Chen et al. 2018). The viability of learning and teaching styles in increasing student performance was widely accepted in the educational community. Besides, investigation in business education research influenced the effort on business students' performance (Johnson et al., 2002; Ferreras-Garcia et al., 2020).

Learning abilities, gender, and race were factors that were reported to affect student performance (Hanson, 2000; Canning et al., (2019)). Simmons et al., (2005) and Bang (2020) surmised that family income levels, full attendance, scholarship obtainment, and top achievement in high schools significantly influenced first-generation college students' performance. Garton et al. (2000) and Mthimunye \& Daniels (2019) conducted studies to evaluate students' efficiency in learning styles and other university admission variables to predict students' academic performance and retention. The study results demonstrated that core Grade Point Average (GPA), English language proficiency, homework completion, and high admission GPA were the most adequate academic performance predictors. Contrarily, Mertler (2004) and Felten et al., (2016) assigned extensive assessment-related activities in classrooms to imply the importance of identifying assessment activities and promote the adoption of desirable achievement goals. Conclusively, the current emphasis on learning improvement assessment indicated the growing importance of faculty engagement in the process (Kinzie et al., 2019; Reder and Crimmins, 2018; Jankowski et al., 2018). 
The exclusion of certain variables served to modify the significance of other determining factors. In some circumstances, inconclusive research results were used as an impetus to change teaching pedagogies (Alton-Lee, 2008; Hunter, 2017; Roose et al., 2019). Particularly, students' learning-teaching interaction was assumed to be a significant factor affecting student performance, and required teachers to adjust teaching styles to facilitate students' learning styles. Although the adoption became widespread and dominated the instruction of many academic institutions, a growing scepticism on the validity of the approach was evident (Crossling et al, 2009; Hosal-Akmana \& Simga-Mugan, 2010; Barry, 2020). Contrary to emphasising the verified methods of student performance improvement, a growing focus on the learning and teaching philosophy was identified despite limited research support. In the absence of an exact active learning definition under CAT, this study adopted the following attributes in line with Bonwell and Eison (1991):

1. Students do not just listen to the lectures, but the individuals display interest in the topic;

2. Students' skills development precedes course content delivery;

3. Students use higher-order thinking levels (analysis, synthesis, and evaluation);

4. Students actively participate during lectures through writing, reading, or discussion;

5. Greater emphasis is placed on students' research on self-assessment and values.

Based on the preceding attributes, active learning invoked students' involvement and facilitated the learning process while practising. Additionally, numerous studies highlighted active learning strategies (Röhl et al, 2013; Bishop \& Verleger, 2012; Tomas et al, 2019; Lundin et al, 2018; Gwo-Jen Hwang, 2019), including visual aids during lectures and encouraging students to write during lectures (note-taking). Collaborative learning through problem-solving was also suggested, such as simulation-based case studies, and problem-based, collaborative, cooperative, or group learning.

Research on student performance included assessment. Undoubtedly, an assessment was the most extensively-used approach in gauging student performance. Traditional assessments involved seven elements: oral exams, true-false questions, multiple-choice, and short-answer questions, matching, completion, and extended short-answer test items (Gronlund, 2006). This study aimed to explore the CAT as an active learning and teaching philosophy to improve student performance.

In Watlings \& Ginsburg (2018), students demonstrated unprecedented performance gains on standardised assessments when learning assessment principles were applied in classrooms with further reiterations that classroom assessments (involving accurate and descriptive feedback to active students) could improve learning. Hence, learning assessments surpassed frequent student assessments to include teachers' collection of assessment results for revised instructions, thus enabling both parties to modify teaching and learning activities.

According to Cross (1989) and Angelo (1991), CAT involved frequent and small-scale assessments conducted in classrooms to improve teaching effectiveness and students' learning quality. Haugen and Becker (2005) reported that students subjected to frequent classroom assessments had significantly higher-level course grades than other students. The assessment was rarely graded or used anonymous instruments and techniques throughout the semester for on-going teaching and learning micro-assessments. Angelo \& Cross (1993) reiterated that classroom assessment strived to improve students' learning quality rather than merely evaluating or grading students with the dual mission of promoting subject-matter learning while providing feedback on teaching effectiveness (Beard, 1993; Carless, 2016; Dawson et el., 2018; Lopez-Pastor \& Sicilia-Camacho, 2017). Hence, CAT aided instructors in shifting the focus from what was being taught to what is being learned and improved the teaching-learning link (Harwood, 1999, Li \& van Lieu, 2018).

A classroom assessment is a technique designed to assist teachers' identification of what and how effective students learn in classrooms to refocus and enhance the teaching quality (Angelo \& Cross, 1993). Cottell (1991) implemented several CAT forms in accounting classes that increased students' learning enjoyment and academic performances in specific tasks. For example, quizzes, homework, and short essay questions were generally useful in promoting learning (Haugen \& Becker, 2005). Angelo and Cross (1993) also emphasised that instructors should aim to provide effective feedback before the midterm or final examinations.

Concerning the EMI impact on students' performance, Harrington and Roche (2014) emphasised the growing need for a post-enrollment assessment to ensure that the enrolled students possessed adequate linguistic resources for academic success. Following Dafouz and Camacho-Minano (2016), EMI was globally becoming a mainstream element among HEIs. Harb's (2009) study on tertiary level students from the United Arab Emirates concluded that students' academic 
performance was dominantly and positively affected by a combination of competence in the English language and class participation. Besides, Feast (2002) affirmed a significantly positive relationship between EP (following the International English Language Testing System scores), and academic performance, (following the GPA). Harb and Shaarawi (2006) also reported that students' English competency had the highest positive impact on student performance. However, a study by Al Zumor (2019) involving tertiary level students from the Saudi Arabia concluded that use of EMI has negative impact on students' comprehensions of the content and ultimately their academic performance.

\section{Method}

\subsection{Samples and Data Collection}

This study adopted quantitative methods, whereby data was collected through a questionnaire survey. The first questionnaire section was designed to obtain information on students' perceptions of whether $t$ instructors' practice of CAT, EP, inadequate accounting textbooks and the orientation of accounting texts'-contents to the Saudi environment. The questionnaire used a five-point Likert scale, ranging from 1 (strongly disagree) to 5 (strongly agree). The first dimension encompassed 11 items measuring the CAT practice (the lack of quizzes and homework collections, and ungraded homework). The second dimension involved three items measuring students' perception of the EP effect (contents of accounting courses insufficiently adapted to the Saudi Arabian environment, and the inadequate scenario and cases in accounting textbooks that proved irrelevantto the Saudi Arabian environment) in academic performance. The second questionnaire section was designed to obtain students' demographic information such as gender, Cumulative Grade Point Average (CGPA), year of study, study major, and age.

The survey was conducted in Arabic before the end of the second semester for the academic year of 2017 and 2018. The targeted groups involved all accounting and non-accounting male and female students at the College of Business Administration. The survey was administered online for male participants, whereas the female counterparts completed the questionnaires during class sessions. The total anticipated study population was 760 students. From the 279 completed surveys, 257 were valid with a response rate of 33.8\%. The study respondents were students enrolled in Accounting, Economics and Finance, Management, and Management Information System (MIS) degree programmes: Specificallt, 25 (9.7\%) participants were male and 232 (90.3\%) participants were female. All four-degree programmes structure were similar during the first year, with students studying and being assessed in Accounting Principles I and II. The participants comprised of $42.8 \%$ accounting majors and $57.2 \%$ non-accounting majors. Specifically, the non-accounting majors encompassed 16.3\% (Economics and Finance), whereas 40.9\% involved Management and MIS majors. Most respondents (55.6\%) achieved CGPAs below 2.5, 37\% achieved CGPAs between 2.5 and 3.5, and only 7.4\% had CGPAs ranging between 3.5 and 4.0. Resultantly, most respondents were in the low academic performance category following the CGPAs.

\subsection{Data Analysis}

The score differences in accounting and non-accounting major-students' responses with the independent t-test were statistically insignificant using independent t-test (see Table 1), hence requiring further analysis for all groups.

Table 1. Independent sample t-test

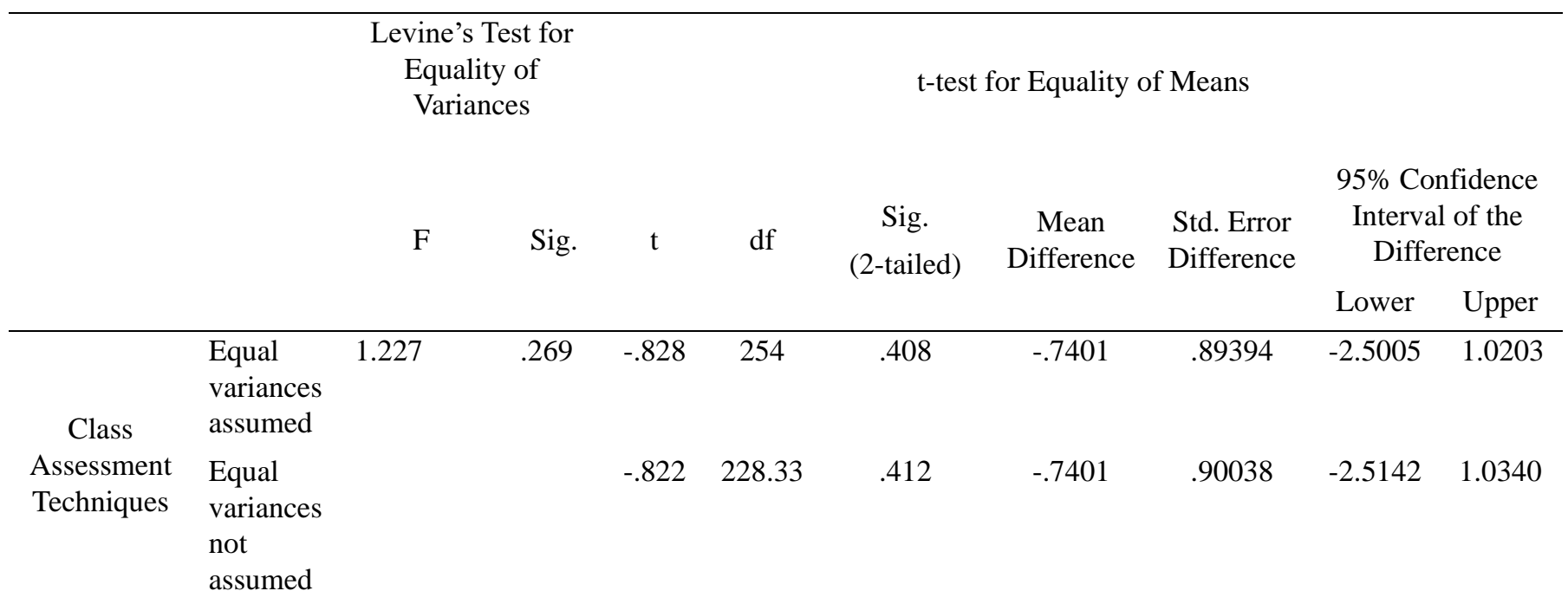




$\begin{array}{llllllllll}\begin{array}{l}\text { Equal } \\ \text { variances } \\ \text { assumed }\end{array} & 2.970 & .086 & 1.713 & 254 & .088 & .4367 & .25501 & -.0654 & .9389 \\ \begin{array}{l}\text { Equal } \\ \text { variances }\end{array} & & & & & & & & & \\ \text { not } \\ \text { assumed }\end{array}$

The Sig. (2-tailed) value in the result read 0.408 for CAT and .088 for EP (exceeding .05), thus reflecting no statistically-significant differences in the perceptions between accounting and non-accounting major students on CAT practices and perceptions of the EP effect in academic performance.

The questionnaire survey data were further examined for internal consistency and reliability using Cronbach's Alpha and validity tests. Table 2 depicts the internal consistency, reliability, validity, and factor loading of the study items. The Cronbach's Alpha value for the CAT and EP dimensions were .733 and .537, respectively. Higher Cronbach's Alpha values corresponded to a more reliable test. Although there was no agreed cut-off point, Nunnally (1978) and Field (2005) argued that a score of 0.5 and above was acceptable. Additionally, the Kaiser-Meyer-Olkin (KMO) measure test verified the sampling adequacy for the analysis with a KMO of .745 for the CAT dimension that exceeded the acceptable limit by Kaiser (1974) and .559 for the EP dimension. As such, the KMO scores in this study were considered high as the scores fell within the range of 0.5 and 0.7 (Hutcheson \& Sofroniou, 1999).

Table 2. Validity and reliability

\begin{tabular}{|c|c|c|c|}
\hline \multicolumn{2}{|l|}{ Coding } & \multirow{2}{*}{$\begin{array}{c}\begin{array}{c}\text { Factor loading of CAT } \\
\text { Dimension }\end{array} \\
.509\end{array}$} & \multirow[t]{2}{*}{$\begin{array}{l}\text { Factor loading of EP } \\
\text { Dimension }\end{array}$} \\
\hline CAT1 & Inadequate quizzes. & & \\
\hline CAT2 & Insufficient homework was assigned. & .600 & \\
\hline CAT3 & Quizzes were conducted with trivial rewards. & .385 & \\
\hline CAT4 & $\begin{array}{l}\text { Homework was randomly collected and } \\
\text { graded. }\end{array}$ & .644 & \\
\hline CAT5 & $\begin{array}{l}\text { Homework collected at the end of class but } \\
\text { not graded or returned. }\end{array}$ & .615 & \\
\hline CAT6 & $\begin{array}{l}\text { Insufficient structured reviews were held } \\
\text { outside regular classes before exams. }\end{array}$ & .421 & \\
\hline CAT7 & $\begin{array}{l}\text { Much focus on multiple-choice questions } \\
\text { without allocating partial credits to students. }\end{array}$ & .408 & \\
\hline CAT8 & The grading scheme is ill-defined. & .601 & \\
\hline СAT9 & $\begin{array}{l}\text { Prolonged delays in providing exam } \\
\text { feedback. }\end{array}$ & .574 & \\
\hline CAT10 & The effort-reward system is flawed. & .432 & \\
\hline CAT11 & Student-faculty interaction is scarce. & .532 & \\
\hline EP1 & $\begin{array}{l}\text { Understanding of accounting principles } \\
\text { course materials hindered by poor English } \\
\text { proficiency. }\end{array}$ & & .520 \\
\hline $\mathrm{EP} 2$ & $\begin{array}{l}\text { Inadequate Saudi-centric adaptation in the } \\
\text { accounting course content. }\end{array}$ & & .812 \\
\hline EP3 & $\begin{array}{l}\text { Inadequate accounting textbooks } \\
\text { highlighting problems and cases relevant to } \\
\text { the Saudi Arabian environment. }\end{array}$ & & .801 \\
\hline KMO an & Bartlett's Test & .745 & .559 \\
\hline Cronbac & 's Alpha & .733 & .537 \\
\hline
\end{tabular}


A variable was not normally distributed if the Kolmogorov-Smirnov (KS) value had a significance of $<0.05$. For example, the KS in Table 3 indicates a non-normal distribution for the EP dimension with a significance of .000 . Regardless, the CAT dimension seemed normal with a significance of $>.05$. The skewness and kurtosis of the distribution were examined to obtain further insights into the normality nature. Notably, the normality assumption was rejected if the skewness was negatively or positively non-symmetrical. Nevertheless, it was reasonable to use statistics that assumed a normal distribution when the sample size exceeded 100 following the Central Limit Theorem.

Table 3. Normality test

\begin{tabular}{lcccc}
\hline \multicolumn{1}{c}{ Variables } & \multirow{2}{*}{ Kurtosis } & Skewness & \multicolumn{2}{c}{ Test of Normality } \\
& & & Kolmogorov-Smirnov & Significance \\
\hline Classroom assessment & -.199 & -.190 & .045 & .200 \\
English proficiency & -.199 & -.471 & .113 & .000 \\
\hline
\end{tabular}

\section{Results and Discussions}

\subsection{Implementation of CAT in Accounting Principles Courses}

Externally, the extraction of students' opinions and responses through an anonymous questionnaire-based survey was the first step towards CAT implementation (Cross \& Angelo, 1988). The approach was employed to achieve the first objective in determining whether teachers' CAT practices in Accounting Principles courses contributed to students' performance. In this vein, the responses were valuable to gauge students' perception of the teaching process.

Most respondents (54.9\%) disagreed that there was a lack of quizzes in the Accounting Principle courses. Interestingly, it was agreed that the quizzes were not acknowledged with significant rewards (48.3\%). Approximately $51.7 \%$ of the students disagreed that there was a lack of homework, whereas $43.6 \%$ stated that homework was collected but randomly graded. Nevertheless, most respondents agreed that assessment feedback, particularly examinations, were not obtained over a reasonable period and poor effort-reward (grade system) was possibly caused by an ill-defined grading scheme. Approximately $122(47.4 \%)$ of the students conceded that student-instructor interactions were scarce.

Undeniably, the results indicated that Accounting Principles course instructors implemented classroom assessments to some extent in the form of quizzes and homework. The assessments were also graded with feedback albeit randomly. The finding corresponded to Angelo and Cross's (1993) conclusion that assessments provided information to guide teachers and students in adjusting towards teaching and learning improvements. Further emphasis on classroom assessments was placed to encourage instructors to become more systematic and sensitive learning observers. Haugen and Becker (2005) reported that quizzes, homework, and short essay questions were often useful learning formats. In this regard, assessments did not necessarily need grading in line with Angelo and Cross (1993). In Haugen and Becker (2005), it was revealed that students subjected to frequent classroom assessments had significantly higher grade levels than other counterparts. Similarly, Cottell (1991) implemented several CAT forms in accounting classes that increased students' learning enjoyment and specific task performance.

A key observation was derived from the exercise on another CAT implementation aspect. Several studies highlighted that regular descriptive feedback to students fostered on-going self-assessment towards what could be construed as quality achievement (Sadler, 1989; ODonovan, 2017; Pereira et al., 2016; Victor Lopez-Pastor \& SiciliaCamacho, 2017). Conversely, students' feedback would guide teachers to apply relevant remedial actions in students' learning improvement. For example, students who were constantly exposed to the quality of visualisation and academic progression would be motivated to bridge the learning gap by adopting the CAT formulae as the next learning step. 
Table 4. Descriptive analysis results depicting the practice of CAT by Accounting Principal instructors

\begin{tabular}{|c|c|c|c|c|c|c|}
\hline Coding & & 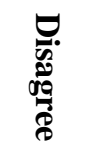 & 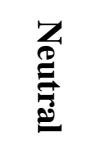 & $\underset{8}{80}$ & $\stackrel{3}{3}$ & $\mathscr{\Omega}$ \\
\hline CAT1 & Inadequate quizzes. & $\begin{array}{c}141 \\
(54.9)\end{array}$ & $\begin{array}{c}56 \\
(21.8)\end{array}$ & $\begin{array}{c}60 \\
(23.3)\end{array}$ & 2.54 & 1.17 \\
\hline CAT2 & Insufficient homework was assigned. & $\begin{array}{c}133 \\
(51.7)\end{array}$ & $\begin{array}{c}60 \\
(23.3)\end{array}$ & $\begin{array}{c}64 \\
(25)\end{array}$ & 2.69 & 1.27 \\
\hline CAT3 & $\begin{array}{l}\text { Quizzes were conducted with a } \\
\text { trivial reward. }\end{array}$ & $\begin{array}{c}50 \\
(19.4)\end{array}$ & $\begin{array}{c}83 \\
(32.3)\end{array}$ & $\begin{array}{c}124 \\
(48.3)\end{array}$ & 3.42 & 1.13 \\
\hline CAT4 & $\begin{array}{l}\text { Homework is randomly collected and } \\
\text { graded. }\end{array}$ & $\begin{array}{c}112 \\
(43.6)\end{array}$ & $\begin{array}{c}74 \\
(28.8)\end{array}$ & $\begin{array}{c}71 \\
(27.6)\end{array}$ & 2.86 & 1.21 \\
\hline CAT5 & $\begin{array}{l}\text { Homework collected at the end of } \\
\text { class but not graded or returned. }\end{array}$ & $\begin{array}{l}121 \\
(47)\end{array}$ & $\begin{array}{c}58 \\
(22.6)\end{array}$ & $\begin{array}{c}78 \\
(30.4)\end{array}$ & 2.81 & 1.29 \\
\hline CAT6 & $\begin{array}{l}\text { Insufficient structured reviews were } \\
\text { held outside regular classes before } \\
\text { exams. }\end{array}$ & $\begin{array}{c}89 \\
(34.6)\end{array}$ & $\begin{array}{c}51 \\
(19.8)\end{array}$ & $\begin{array}{c}117 \\
(45.6)\end{array}$ & 3.26 & 1.41 \\
\hline CAT7 & $\begin{array}{l}\text { Much focus on multiple-choice } \\
\text { questions without allocating partial } \\
\text { credit to students. }\end{array}$ & $\begin{array}{c}75 \\
(29.2)\end{array}$ & $\begin{array}{c}76 \\
(29.6)\end{array}$ & $\begin{array}{c}106 \\
(41.2)\end{array}$ & 3.22 & 1.21 \\
\hline CAT8 & The grading scheme is ill-defined. & $\begin{array}{c}50 \\
(19.5)\end{array}$ & $\begin{array}{c}72 \\
(28)\end{array}$ & $\begin{array}{c}135 \\
(52.5)\end{array}$ & 3.64 & 1.22 \\
\hline CAT9 & $\begin{array}{l}\text { Prolonged delay in providing exam } \\
\text { feedback. }\end{array}$ & $\begin{array}{c}58 \\
(22.6)\end{array}$ & $\begin{array}{c}52 \\
(20.2)\end{array}$ & $\begin{array}{c}147 \\
(57.2)\end{array}$ & 3.64 & 1.20 \\
\hline CAT10 & The effort-reward system is flawed. & $\begin{array}{c}34 \\
(13.3)\end{array}$ & $\begin{array}{c}41 \\
(16)\end{array}$ & $\begin{array}{c}182 \\
(70.7)\end{array}$ & 3.92 & 1.15 \\
\hline CAT11 & Student-faculty interaction is scarce. & $\begin{array}{c}57 \\
(22.2)\end{array}$ & $\begin{array}{c}78 \\
(30.4)\end{array}$ & $\begin{array}{c}122 \\
(47.4)\end{array}$ & 3.46 & 1.21 \\
\hline
\end{tabular}

3.2 Students' Perception of the EP Effect and Inadequate Accounting Textbook Content Oriented on the Saudi Arabian Environment Regarding Performance

The study examined students' perception of whether EP and the inadequate availability of accounting textbooks with content oriented to the Saudi Arabian environment affected academic performance. The EMIs in accounting have steadily become mainstream in Saudi Arabian HEIs. Academicians and students believed that teaching the accounting curriculum in English could increase accounting graduates' marketability (Srdar, 2017). Dafouz and Camacho-Minano (2016) emphasised that accounting students and graduates needed English mastery following the globalised economy that culminated in the growth of multinational companies.

As the Accounting Education Curriculum by the International Federation of Accountants (IFAC) and International Financial Reporting Standards (IFRS) was entirely in English, the international business community has extensively adopted English as the primary external reporting language following foreign ownership prominence. Additionally, 
Srdar (2017) highlighted that most Saudi Arabian private sector companies expected acceptable English competency as an employment criterion.

Resultantly, almost all (79\%) students agreed that poor EP hindered the understanding of accounting materials. The situation was exacerbated by insufficient accounting textbooks and course learning materials relevant to the Saudi Arabian environment. It was further observed that current reference materials were entirely adopted in content, style, culture, and implementation from American textbooks which could be ambiguous in context and practice. Following Table 5, 50.8\% and 55.8\% of the students perceived that Accounting Principles course contents were insufficiently adapted to the Saudi Arabian environment and adequate textbooks in principle accounting courses were scarce and potentially contributed to low performance.

Table 5. Descriptive analysis results on students' perception of EP, accounting textbook, and content.

\begin{tabular}{|c|c|c|c|c|c|c|}
\hline Coding & & 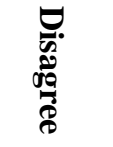 & $\underset{\Xi}{Z}$ & $\frac{\sqrt{0}}{8}$ & $\stackrel{3}{3}$ & $\mathscr{\theta}$ \\
\hline EP1 & $\begin{array}{l}\text { Understanding of the accounting } \\
\text { principles course materials hindered by } \\
\text { poor English proficiency. }\end{array}$ & $\begin{array}{c}25 \\
(9.8)\end{array}$ & $\begin{array}{c}29 \\
(11.3)\end{array}$ & $\begin{array}{c}202 \\
(79.0)\end{array}$ & 4.23 & 1.05 \\
\hline EP2 & $\begin{array}{l}\text { Inadequate Saudi-centric adaptation } \\
\text { among accounting course content. }\end{array}$ & $\begin{array}{c}55 \\
(21.5)\end{array}$ & $\begin{array}{c}71 \\
(27.7)\end{array}$ & $\begin{array}{c}130 \\
(50.8)\end{array}$ & 3.51 & 1.18 \\
\hline EP3 & $\begin{array}{l}\text { Inadequate textbooks in accounting } \\
\text { highlighting problems and cases } \\
\text { oriented to the Saudi Arabian } \\
\text { environment. }\end{array}$ & $\begin{array}{c}50 \\
(19.6)\end{array}$ & $\begin{array}{c}63 \\
(24.6)\end{array}$ & $\begin{array}{c}143 \\
(55.8)\end{array}$ & 3.58 & 1.19 \\
\hline
\end{tabular}

\section{Conclusion and Limitations}

Given the vast study implications and scope, this research highlighted two objectives: to determine whether teachers' CAT practice or implementation of in Accounting Principles courses contributed to students' performance and examine students' perception of whether EP and inadequate accounting textbook content affected performance. The study aimed to emphasise student performance as an implied construct that catalysed the first two objectives rather than true performance. The study outcomes on undergraduate students' performance on accounting principle courses at the University of Hail predictably offered much insight into implementing an initiative to improve students' performance through CAT.

The overall performance of undergraduates taking Accounting Principles courses was primarily skewed to lower performance. Generally, the university would be urged to implement appropriate measures for student performance improvement. Nevertheless, the documented low performance was not alarming considering the various factors impeding students' academic performance. This study further analysed the factors to open channels or opportunities that implemented active teaching-learning pedagogical approaches to boost student performance. Following the survey response analyses, the students were encumbered by key factors that adversely affected performance. The principal issue among the responses was the lack of EP involving instructions, reference materials, textbooks, assignments, quizzes, and examinations conducted in English. In this vein, students were at a disadvantage from the beginning.

The survey responses also indicated that students needed more quizzes and interactions with instructors to retain high enthusiasm and the motivation to excel in Accounting Principles courses. The studies concluded that pre-examination interventions, previews, and tutorials were effective approaches to improve student learning, retention, and critical thinking, and key classroom activities to improve student performance (Becker, 2013; Sargent et. al., 2011; Young and Warren, 2011, Randolph, 2020, Terblanche \& de Clercq, 2020). Thus, it was relevant to suggest that teachers consider adopting an approach that facilitated students' examination preparation with pre-examination reviews and other learning interventions (tutorials).

Consequently, the study outcomes recommended intervention opportunities to improve student performance while conceding that the university presented a viable opportunity to implement CAT as an active learning approach for improved student performance. Several key observations contributed to students' low performance. Typically, students 
attended classes despite the lack of appropriate mental or psychological acumen for learning engagement. Inappropriately, many students viewed university attendance akin to a rite-of-passage to adulthood rather than an opportunity to acquire the necessary skills of a dynamic workforce.

Students were more likely conditioned towards conventional teaching methods in school without the appropriate motivation to pursue an excellent university education. Another observation involved the lack of positive interactions between teachers and students in and out of classes following relevant works of literature (Astin, 1993; Pascarella \& Terenzini, 2005). Although some of the authentic active learning effects might not have been detected (the survey did not include the aim), a keen effort to cross-reference established concepts positively impacted student performance. A significant and relevant factor involved teachers' ability to gauge teaching method effectiveness as the contributing elements towards student performance improvement. Hence, CAT facilitated teachers to achieve educational objectives while improving teacher-student interactions.

This study justified the significance of EP among students (response and performance-wise). Although most students perceived Accounting Principles course performance to be hinged on EP, the availability of adequate textbooks and study materials in English oriented towards the prevailing Saudi Arabian environment significantly influenced students' perceptions of low performance. As the resultant unfamiliarity was a major regression for students, the gravity of the situation was not just an impediment involving inadequate language proficiency, but the circumstance involved adequate and appropriate class materials.

Conclusively, several suggestions could be made to improve students' performances and current teaching approaches. For example, universities could implement a more structured CAT programme to establish and create an effective and active teaching-learning environment for students. The implementation should enable teachers to monitor and measure the effectiveness of teaching approaches for continued improvement. Although CAT is currently being practised, a structured basis remained lacking.

Universities could also attempt to offer textbooks and teaching materials that were relevant to the Saudi Arabian environment. For example, manuals and case studies should correspond to the existing conditions in Saudi Arabia. By enabling students to use the materials in an active and EP environment, the students would begin to show improved performance. The development of specific disciplinary-literacy in EMI and communication would tremendously benefit students globally if the students intended to pursue such potential.

Saudi Arabia has identified education as the pivotal catalyst of Vision 2030 (directed towards national economic transformation) from dependence on petroleum to an economy characterised by diversity, including industry, manufacturing, primary productivity, and adequately-trained and skilled populace. Furthermore, the government aspired to implement significant changes in higher education (through the National Transformation Programme) to produce educated, skilled, and motivated human resources (younger generations) that supported the vision of an economy that was no longer primarily dependent on petroleum.

Higher education transformations witnessed an increasing diversity among HEI students in Saudi Arabia. Students from different social and cultural backgrounds, experiences, and educational levels brought different needs and academic potentials. The challenge for Saudi Arabian universities was in recognising the diversity of needs that catered to a dynamic and heterogeneous student population. The emphasis should not only be on admitting a more extensive range of students, but the focus should be on ample and appropriate support for a reasonable chance to achieve Vision 2030.

Several study limitations served as important factors to be addressed for future research in this area. The limitations hinged on low reliability estimates from the self-reported questionnaires for several reasons. The identified reasons included the replication of questionnaire items from a previous study conducted in a Saudi Arabian university. Regardless, some of the items or instructions might not have been clearly expressed, thus causing participants to misinterpret the items and lowering the internal consistency of the responses. Additionally, the inclusion of a neutral response in the five-point Likert-scale potentially reduced the variances (apart from inducing a central tendency) and possibly contributed to lower reliability estimates.

\section{References}

Alton-Lee A. (2008). Making a Bigger Difference for Diverse Learners: The Iterative Best Evidence Synthesis Programme in New Zealand. In: Wan G. (eds) The Education of Diverse Student Populations. Explorations of Educational Purpose, vol 2. Springer, Dordrecht. https://doi.org/10.1007/978-1-4020-8204-7_13

Al Zumor, Abdulwahid Qasem. (2019). Challenges of Using EMI in Teaching and Learning of University Scientific Disciplines: Student Voice. International Journal of Language Education, Vol. 3, No. 1, 74-90. 
https://doi.org/10.26858/ijole.v1i1.7510

Andrade, H. L., \& Brookhart, S. M. (2020). Classroom assessment as the co-regulation of learning, Assessment in Education: Principles, Policy \& Practice, 27:4, 350-372. https://doi.org/10.1080/0969594X.2019.1571992

Angelo, T. A. (1991). 'Introduction and Overview: from classroom assessment to classroom research', in Angelo, T.A. (Ed.): Classroom Research: Early Lessons from Success, Jossey-Bass, San Francisco. https://eric.ed.gov/?id=EJ431497

Angelo, T. A., \& Cross, K. P. (1993). Classroom Assessment Techniques. A Handbook for College Teachers. $2^{\text {nd }}$ ed. Jossey-Bass, San Francisco. https://doi.org/10.1002/tl.37219914603

Astin, A.W. (1993). What Matters in College? Four Critical Years Visited. San Francisco. Jossey-Bass.

Bang, S. H. (2020). First-Generation College Persistence: University-Assisted Schools and Their Influence on College Degree Attainment. UCLA. ProQuest ID: Bang_ucla_0031D_19065. Merritt ID: ark:/13030/m59p8d2z. https://escholarship.org/uc/item/4mx0n603

Barry, M. (2020). Global challenges, global citizenship: what is the local classroom reality? A qualitative case study of global citizenship education teaching and learning practices. $\mathrm{PhD}$ thesis, Dublin City University. http://doras.dcu.ie/24983/1/FINAL\%20FOR\%20PRINT\%20Thesis\%20Maria\%20Barry.pdf

Beard, V. (1993). Classroom assessment techniques (CATs): Tools for improving accounting education. Journal of Accounting Education, 11(2), 293-300. https://doi.org/10.1016/0748-5751(93)90009-8

Becker, L. L. (2013). Self-Regulated Learning Intervention in the Introductory Accounting Courses: An Empirical Study. Issues in Accounting Education, Vol. 28, No. 3, 435-460. https://doi.org/10.2308/iace-50444

Bishop, J., \& Verleger, M. (2013). "Testing the flipped classroom with model-eliciting activities and video lectures in a mid-level undergraduate engineering course," 2013 IEEE Frontiers in Education Conference (FIE), Oklahoma City, OK, USA, 2013, 161-163. https://doi.org/10.1109/FIE.2013.6684807

Bonwell, C. C., \& Eison, J. (1991). Active learning: Creating excitement in the classroom. ASHE-ERIC Higher Education Report (No. 1). Washington, DC: The George Washington University School of Education and Human Development. https://files.eric.ed.gov/fulltext/ED336049.pdf

Brookhart, S. M. (1997). A theoretical framework for the role of classroom assessment in motivating student effort and achievement. Applied measurement in education, 10(2), 161-180. https://doi.org/10.1207/s15324818ame1002_4

Cambridge University Reporter. (2003). Indicators of academic performance. http://www.admin.cam.ac.uk/reporter/2002-03/weekly/5915/

Canning, E. A., Muenks, K., Green, D. J., \& Murphy, M. C. (2019). STEM faculty who believe ability is fixed have larger racial achievement gaps and inspire less student motivation in their classes. Science Advances, Vol. 5, no. 2, 1-7, eaau4734 (2019). https://doi.org/10.1126/sciadv.aau4734

Carless, D. (2016). Feedback as Dialogue. M.A. Peters (ed.), Encyclopedia of Educational Philosophy and Theory. https://doi.org/10.1007/978-981-287-532-7_389-1

Chen, C., Jones, K., \& Xu, S. Z. (2018). The Association between Students' Style of Learning Preferences, Social Presence, Collaborative Learning and Learning Outcomes. Journal of Educators Online, 15. https://doi.org/10.9743/JEO2018.15.1.3

Chen, P. H. (2019). In-class and after-class lecture note-taking strategies. Active Learning in Higher Education, 146978741989349. https://doi.org/10.1177/1469787419893490

Chickering, A. W., \& Gamson, Z. F. (1987) 'Seven principles for good practice in undergraduate education', American Association for Higher Education Bulletin, March, 3-7. https://files.eric.ed.gov/fulltext/ED282491.pdf

Cottell, P. G. (1991). 'Classroom research in accounting: assessing for learning', in Angelo, T.A. (Ed.): Classroom Research: Early Lessons from Success, Jossey-Bass, San Francisco. https://doi.org/10.1002/tl.37219914606

Crosling, G., Heagney, M., \& Thomas, L. (2009) Improving Student Retention in Higher Education: Improving teaching and learning. In Australian Universities' Review, Vol.51, No. 2, 9-18. (https://files.eric.ed.gov/fulltext/EJ864028.pdf).

Cross, K. P. (1989). What's in that black box?, or, How do we know students are learning? Howard R. Bowen lecture 
at the Claremont Graduate School, Claremont, CA. Quoted in Angelo, TA (1991). Introduction and overview: from classroom assessment to classroom research. Classroom Research: Early lessons from success, (46), 7-15. https://doi.org/10.1002/tl.37219914603

Cross, K. P., \& Angelo, T. A. (1988) Classroom Assessment Techniques. A Handbook for Faculty. Ann Arbor, MI: National Center for Research to Improve Postsecondary Teaching and Learning. https://files.eric.ed.gov/fulltext/ED317097.pdf

Dafouz, E., \& Mar Camacho-Minano, M. (2016). Exploring the impact of English-medium instruction on University student achievement: The case of accounting, English for Specific Purposes, 44(2016), 57-67. https://doi.org/10.1016/j.esp.2016.06.001

Dawson, P., Henderson, M., Mahoney, P., Phillips, M., Ryan, T., Boud, D., \& Molloy, E. (2018). What makes for effective feedback: staff and student perspectives. Assessment \& Evaluation in Higher Education, 1-12. https://doi.org/10.1080/02602938.2018.1467877

Feast, V. (2002). “The impact of IELTS scores on performance at university", International Education Journal, Vol. 3, No. 4, 70-85. http://citeseerx.ist.psu.edu/viewdoc/download?doi=10.1.1.457.4736\&rep=rep1\&type=pdf

Ferreras-Garcia, R., Ribas, C., Sales-Zaguirre, J., \& Serradell-López, E. (2020). Competencies in business degrees: A face-to-face and online comparative study. Journal of Education for Business, 1-11. https://doi.org/10.1080/08832323.2020.1751025

Field, A. (2005). Discovering statistics with SPSS. London: Sage Publications.

Garton, B. L., Dyer, J. E., \& King, B. O. (2000). The Use of Learning Styles and Admission Criteria in Predicting Academic Performance and Retention of College Freshmen. Journal of Agriculture Education, 41(2), 46-53. https://doi.org/10.5032/jae.2000.02046

Gronlund, N. E. (2006). Nature of student assessment. Assessment of Student Achievement, 8th Edition, Pearson, Boston, 14-30.

Gwo-Jen Hwang, Chengjiu Yin \& Hui-Chun Chu (2019) The era of flipped learning: promoting active learning and higher order thinking with innovative flipped learning strategies and supporting systems, Interactive Learning Environments, 27:8, 991-994. https://doi.org/10.1080/10494820.2019.1667150

Hanson, J. (2016). Surveying the experiences and perceptions of undergraduate nursing students of a flipped classroom approach to increase understanding of drug science and its application to clinical practice. Nurse Education in practice. Vol. 16, Issue 1, 79-85. https://doi.org/10.1016/j.nepr.2015.09.001

Hanson, J. B. (2000). Student performance and student growth as measure of success: A evaluator's perspective. Paper presented at annual meeting of the American educational research association New Orleans. Louisiana. 25 April. (https://files.eric.ed.gov/fulltext/ED443876.pdf)

Harb, N., \& El-Shaarawi, A. (2006). Factors affecting students' performance (Munich Personal RePEc Archive Paper No. 13621). https://mpra.ub.uni-muenchen.de/13621/1/MPRA_paper_13621.pdf

Harlen, W., \& Crick, R. D. (2003). Testing and motivation for learning. Assessment in Education: Principles, Policy \& Practice, 10, 169-207. https://doi.org/10.1080/0969594032000121270

Harrington, M., \& Roche, T. (2014). Identifying academically at-risk students in an English-as-a-Lingua-Franca university setting. Journal of English for Academic Purposes, Vol. 15, 37-47. https://doi.org/10.1016/j.jeap.2014.05.003

Harwood, E. M. (1999). Students' perceptions of effects of classrooms assessment techniques (CATs). Journal of Accounting Education, Vol. 17, Issue 1, 51-70. https://doi.org/10.1016/S0748-5751(99)00003-2

Haugen, S., \& Becker, D. (2005). Classroom assessment and accounting student performance. Int. J. Innovation and Learning, 2(1), 36-46. https://doi.org/10.1504/IJIL.2005.006082

Hosal-Akmana, N., \& Simga-Mugan, B. (2010). An assessment of the effects of teaching methods on academic performance of students in accounting courses. Innovations in Education and Teaching International Vol. 47, No. 3, August 2010, 251-260. https://doi.org/10.1080/14703297.2010.498176

Hunter, J. (2017). High Possibility Classrooms as a pedagogical framework for technology integration in classrooms: an inquiry in two Australian secondary schools. Technology, Pedagogy and Education, 26(5), 559-571. https://doi.org/10.1080/1475939X.2017.1359663 
Hutcheson, G., \& Sofroniou, N. (1999). The multivariate social scientist: introductory statistics using generalized linear models. Thousand Oaks, CA: Sage Publications

Ilie, S., \& Lietz, P. (2010). School quality and student achievement in 21 European countries: The Heyneman-Loxley effect revisited. In IERI Monograph Series. Issues and Methodologies in Large-scale Assessments (Vol. 3, pp. 57-84). IEA-ETS Research Institute. (ISBN:9788868540968) https://researchnow.flinders.edu.au/en/publications/school-quality-and-student-achievement-in-21-european-coun tries-t

Jankowski, N. A., Timmer, J. D., Kinzie, J., \& Kuh, G. D. (2018). Assessment That Matters: Trending toward Practices That Document Authentic Student Learning. National Institute for Learning Outcomes Assessment. Report. https://files.eric.ed.gov/fulltext/ED590514.pdf

Johnson, D. L., Joyce, P., \& Sen, S. (2002). An analysis of student effort and performance in the finance principles course. Journal of Applied Finance, Vol.12, No. 2, 67-72. SSRN: https://ssrn.com/abstract=360400

Kaiser, H. F. (1974). An index of factorial simplicity. Psychometrika, 39(1), 31-36. https://doi.org/10.1007/BF02291575

Kinzie, J., Landy, K., Sorcinelli, M. D., \& Hutchings, P. (2019). Better Together: How Faculty Development and Assessment Can Join Forces to Improve Student Learning. Change: The Magazine of Higher Learning, 51(5), 46-54. https://doi.org/10.1080/00091383.2019.1652076

Li, M. van Lieu, S. (2018). Traditional and Online Faculty Members' Use of Classroom Assessment Technique (CATs): A Mixed-Method Study. Journal of Instructional Research, v7, 90-99. https://doi.org/10.9743/JIR.2018.8

Lundin, M., Bergviken Rensfeldt, A., \& Hillman, T. (2018). Higher education dominance and siloed knowledge: a systematic review of flipped classroom research. Int $J$ Educ Technol High Educ 15, 20, 1-30. https://doi.org/10.1186/s41239-018-0101-6

Mertler, C. (2004). Secondary Teachers' Assessment Literacy: Does Classroom Experience Make A Difference? American Secondary Education, 33(1), 49-64. https://www.jstor.org/stable/41064623

Mthimunye, K., \& Daniels, F.M. (2019). Predictors of academic performance, success and retention amongst undergraduate nursing students: a systematic review. South African Journal of Higher Education. Volume 33, Number 1, 2019, 200-220. https://doi.org/10.20853/33-1-2631

Nunnally, J. C. (1978). Psychometric theory. 2nd Edition, McGraw-Hill, New York.

O’Donovan, B. (2017). How student beliefs about knowledge and knowing influence their satisfaction with assessment and feedback. Higher Education. Vol. 74, 617-633. https://doi.org/10.1007/s10734-016-0068-y

Onay, A., \& Benligiray, S. (2018). Internal factors affecting student performance in accounting courses at a vocational school. Sumerianz Journal of Economics and Finance, 1(3), 82-90. File URL: http://www.sumerianz.com/pdf-files/sjef1(3)82-90.pdf

Papageorgiou, E., \& Callaghan, C. W. (2020). Accountancy learning skills and student performance in accounting education: evidence from the South African context. Accounting Education, 1-24. https://doi.org/10.1080/09639284.2020.1719426

Pascarella, E. T., \& Terenzini, P. T. (2005). How College Affects Students: A Third Decade of Research. Volume 2. Jossey-Bass, An Imprint of Wiley. 10475 Crosspoint Blvd, Indianapolis, IN 46256.

Penuel, William R., \& Lorrie A. Shepard. 2016. Assessment and teaching. In Handbook of research on teaching, 5th ed., eds. Drew H. Gitomer and Courtney A. Bell, 787-850. Washington, DC: American Educational Research Association. https://doi.org/10.3102/978-0-935302-48-6_12

Pereira, D., Flores, M. A., Simão, A. M. V., \& Barros, A. (2016). Effectiveness and relevance of feedback in Higher Education: A study of undergraduate students. Studies in Educational Evaluation, Vol. 49, 7-14. https://doi.org/10.1016/j.stueduc.2016.03.004

Randolph Nsor-Ambala (2020). Impact of exam type on exam scores, anxiety, and knowledge retention in a cost and management accounting course, Accounting Education, 29:1, 32-56. https://doi.org/10.1080/09639284.2019.1683871

Reder, M., \& Crimmins, C. (2018). (Why Assessment and Faculty Development Need each other: Notes on Using Evidence to Improve Student Learning. Research and Practice in Assessment. Vol. 13, 15-19. 
(https://files.eric.ed.gov/fulltext/EJ1206357.pdf)

Roose, I., Vantieghem, W., Vanderlinde, R., \& Van Avermaet, P. (2019). Beliefs as filters for comparing inclusive classroom situations. Connecting teachers' beliefs about teaching diverse learners to their noticing of inclusive classroom characteristics in videoclips. Contemporary Educational Psychology, 56, 140-151. https://doi.org/10.1016/j.cedpsych.2019.01.002

Röhl, A., Reddy, S., \& Shannon, G. J. (2013). The Flipped Classroom: An Opportunity to Engage Millennial Students through Active Learning Strategies. Journal of Family and Consumer Sciences, 105, 44-49. https://doi.org/10.14307/JFCS105.2.12

Roth, P. L., BeVier, C. A., Switzer, F. S. III, \& Schippmann, J. S. (1996). Meta-analyzing the relationship between grades and job performance. Journal of Applied Psychology, 81(5), 548-556. https://doi.org/10.1037/0021-9010.81.5.548

Romer, D. (1993). Do Students Go to Class? Should They? Journal of Economic Perspectives, vol. 7, no. 3, 167-174. https://doi.org/10.1257/jep.7.3.167

Sadler, R. (1989). Formative assessment and the design of instructional systems. Instructional Science, 18, 119-144. https://doi.org/10.1007/BF00117714

Sargent, C. S., Borthick, A. F., \& Lederberg, A. R. (2011). Improving Retention for Principles of Accounting Students: Ultra-short Online Tutorials for Motivating Effort and Improving Performance. Issues in Accounting Education, Vol. 26, No. 4, 657-679. https://doi.org/10.2308/iace-50001

Shareef, M. A., AlAmodi, A. A., Al-Khateeb, A. A., Abudan, Z., Alkhani, M. A., Zebian, S. I., \& Tabrizi, M. J. (2015). The interplay between academic performance and quality of life among preclinical students. BMC medical education, Vol. 15 (1), 1-8. https://doi.org/10.1186/s12909-015-0476-1

Shepard, Lorrie A. (2006). Classroom assessment. In Educational measurement, 4th ed., ed. Robert L. Brennan, 623-46. Westport, CT: Praeger.

Shepard, Lorrie A., William R. Penuel, \& James W. Pellegrino. (2018). Using learning and motivation theories to coherently link formative assessment, grading practices, and large-scale assessment. Educational Measurement: Issues and Practice, 37(1), 21-34. https://doi.org/10.1111/emip.12189

Shepard, L. A. (2019). Classroom Assessment to Support Teaching and Learning. The ANNALS of the American Academy of Political and Social Science, Vol. 683 (1), 183-200. https://doi.org/10.1177/0002716219843818

Simmons, A. B., Musoba, G. D., \& Choong, C. G. (2005). Persistence Among First Generation College Students in Indiana: The Impact of Precollege Preparation, College Experiences, and Financial Aid. Indian Project on Academic Success (IPAS) Research Report \# 05-01

Srdar, Nujoud Abdulhadi. (2017). The gap between learning and teaching in Accounting Education: The Saudi Arabian Experience. Unpublished $\mathrm{PhD}$ Thesis. University of Portsmouth, United Kingdom. https://researchportal.port.ac.uk/portal/files/7664062/Nujoud_Srdar_Thesis_Final_draft.pdf

Terblanche, E. A. J., \& de Clercq, B. (2020) Factors to consider for effective critical thinking development in auditing students, South African Journal of Accounting Research, 34:2, 96-114. https://doi.org/10.1080/10291954.2019.1669293

Tomas, L., \& Evans, N. (2019). Doyle, T. et al. Are first year students ready for a flipped classroom? A case for a flipped learning continuum. Int $J$ Educ Technol High Educ, 16, 5, 1-22. https://doi.org/10.1186/s41239-019-0135-4

Victor López-Pastor \& Alvaro Sicilia-Camacho. (2017). Formative and shared assessment in higher education. Lessons learned and challenges for the future, Assessment \& Evaluation in Higher Education, 42:1, 77-97. https://doi.org/10.1080/02602938.2015.1083535

Visser, S., McChlery, S., \& Vreken, N. (2006), "Teaching styles versus learning styles in the accounting sciences in the United Kingdom and South Africa: a comparative analysis", Meditari Accountancy Research, Vol. 14 No. 2, 97-112. https://doi.org/10.1108/10222529200600015

Vruwink, D. R., \& Otto, J. R. (1987). Evaluation of teaching techniques for introductory accounting courses. The Accounting Review, vol. LXII, no. 2, 402-408. https://www.jstor.org/stable/247935

Watling, C. J., \& Ginsburg, S. (2018). Assessment, feedback and the alchemy of learning. Medical 
Education. https://doi.org/10.1111/medu.13645

Young. M., \& Warren D. L. (2011). Encouraging the Development of Critical Thinking Skills in the Introductory Accounting Courses Using the Challenge Problem Approach. Issues in Accounting Education, November 2011, Vol. 26, No. 4, 859-881. https://doi.org/10.2308/iace-50065

\section{Copyrights}

Copyright for this article is retained by the author(s), with first publication rights granted to the journal.

This is an open-access article distributed under the terms and conditions of the Creative Commons Attribution license (http://creativecommons.org/licenses/by/4.0/). 